\title{
Rural Private Defenses in the Venetian Stato da Mar
}

\section{Dragos Cosmescu}

Universitatea Maritimă Constanta, Constanta, Romania, dragos.cosmescu@yahoo.com

\begin{abstract}
The paper will investigate the fortifications erected by private entities in rural areas throughout the Stato da Mar territories of the Republic of Venice. While the state structures are definitely more studied, the private Venetian defenses of the territory are mostly ignored from a comparative discussion encompassing a larger area. The defenses constructed by the noble families differ in type and layout, depending on their location and destination: there are inland tower houses in Crete designed to control the territory against native uprisings, and there are seaside castles in Dalmatia that are also considering naval raids. We will analyze these private Venetian defenses in their variety and importance for their regions and the Republic.
\end{abstract}

Keywords: Private defenses, rural area, Venetian, Stato da Mar.

\section{Introduction}

In this paper we will present some best known examples, to introduce the reader in the subject, and also introduce two unexplored items. This is by no means exhaustive comparison of Venetian private rural defenses, but an overview of the architypes, exemplified in showcase items, along with an introduction to two previously undocumented fortified private compounds.

We will see distinctions coming from their structure, history of construction, relations to the environment, morphology, exposure to enemy threats.

Inland Istria, we can find substantial private defenses such as Morosini-Grimani castle (Svetvinčenat) and Soardo-Bembo castle (Bale), from the sixteenth century. In Dalmatia, the most important private defenses are seaside castles in an area known as Sette Castelli (Kastela). Only some of them can be classified as private defenses, such as the castles of the families Vitturi (Lukšić), Cambi (Kambelovac) and StafileoRotondo (Štafilić). Their structures are more compact than those in Istria, and they usually carry the same square layout jutting from the shore, with a small wet moat around.
In the eastern territories of the Republic of Venice, the private structures outside the large walled cities were mostly confined to tall tower houses inland. Similar tower houses are in Maroulas, close to Rethymnon, the most remarkable expression of tower houses on the island of Crete, where other private rural defenses existed in abundance (Voila, Vainas, Kornaros, etc.). An interesting and understudied private rural defense of the Venetian period is the tower house in area of Acharavi (Corfu).

\section{Istria}

The Istrian castles presented here are in the interior of the peninsula, but were actually built close to the border between Venice and the Habsburgs (or other regional entities: Bishopric of Porec, Patriarchate of Aquileia), on a border which became specifically active during the Uskocs war (1615-1618).

The Morosini-Grimani Castle in Svetvinčenat (Croatia) is named after the most important families that owned it (since 1384/1523, and 1560 respectively). The castle perimeter is rectangular, with two round towers on its northern cor- 
ners, and a square tower in the southeast. Originally, there was a lone tower-house, whose design is similar to the tower in Acharavi (Crete) or the keep of Sitia citadel (Crete). It has 4 floors, and access was through a doorway on the first floor, over a stone staircase.

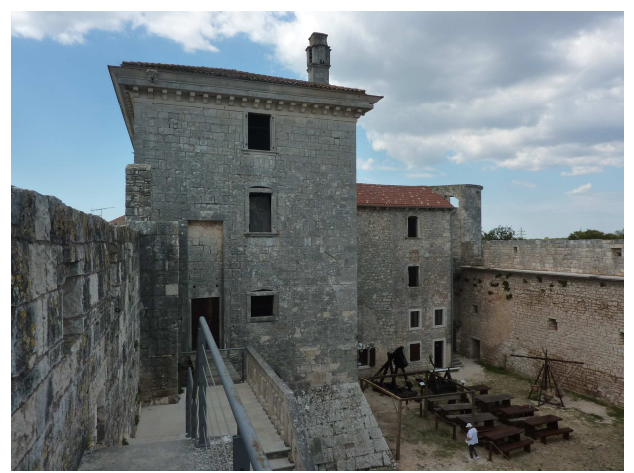

Fig. 1. Morosini-Grimani castle (Dragos Cosmescu).

It later added the square tower with a very slanted portion added to its ground floor, followed by two round towers, in the late Middle Ages, with interior structures similar with the same forms present in Korcula, Trogir, Ston or Piran. Eventually, all these were connected with a curtain wall $10 \mathrm{~m}$ high, with wallwalk and loopholes. The fort entrance was through a drawbridge (whose slots are still present), situated in an area of the curtain defended by the main structure, which by now had become the keep. Above the entrance are dedications for the renovation of the castle (1589), as well as the coats of the arms of the Grimani family. Later, more facilities were added to west of the initial tower-house (fondaco, barracks, etc.).

In Bale, the village center is occupied by the Bembo-Soardo castle. Here the castle developed as part of the settlement' walled enclosure, above the town gate and between the two towers of defensive walls. The space between the two towers has been gradually filled with private accommodations, until their defensive role was lost to esthetic considerations. The GothicRenaissance facade is decorated west with two wide quadrifores on the first and the second floor, while the towers have simple Gothic windows. One of the towers also harbors a gate with Gothic arch, and a solar clock, a Lion of St. Mark and the coat of arms of the family Bembo are placed above it.

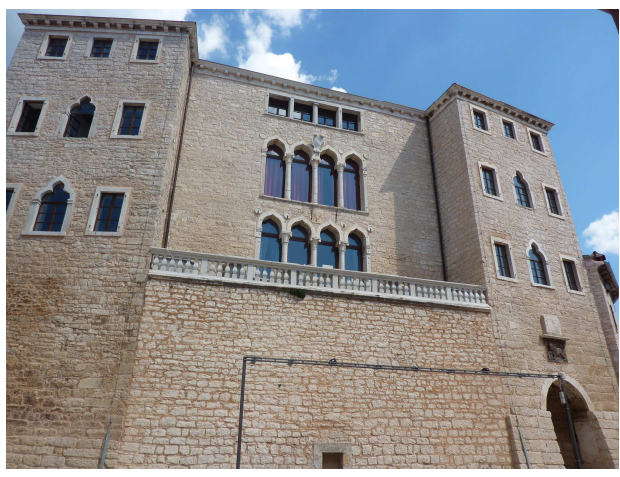

Fig. 2. Bembo-Soardo castle (Dragos Cosmescu).

Today the Bale town walls are incorporated into the houses, and apart from the castle, other two towers are preserved, in various phases of preservation.

\section{Dalmatia}

After the fall of Bosnia (1463), the Dalmatian coastline faced the danger from the Ottoman raids, enhanced by the loss of the key strategic fortress of Klis (1537). The exposed seaside plain inhabitants retreated to the protection of many castles and fortified villages on the coast between Split and Trogir, built by local noblemen and entities (the Split archbishopric, the Benedictine monastic order).

These private defensive structures were directly on the sea close to the shore, in order to protect the population and secure the agricultural production (vineyards, olive groves). Along the coast, from Trogir to Split, these forts are, in order: Štafilić, Novi, Stari, Lukšić, Kambelovac, Gomilica and Sućurac. Alongside these are found several other towers (Ferro, Lodi, etc.).

Castles like Sućurac, Stari or Lukšić are fortified mansion features on land sides moats, loopholes and drawbridges, while the side facing the sea was built as Renaissance villas. They present interior yards with arcades and decorated balconies and windows in High Gothic style.

The Lukšić Castle was built by the aristocratic family Vitturi from Trogir, at the end of the fifteenth century, and consist of residential twostory building. There are only 2 towers, towards the mainland, and no specific military features on the western seaward approaches. Their base is slanted and the ground level looks smaller now because the moat has been largely filled. 
An inverted loophole gunport is encountered in the north-western tower. The curtain between the towers was engrossed with chambers and enhanced the wall and allows the placing of a large machicolation over the entrance.

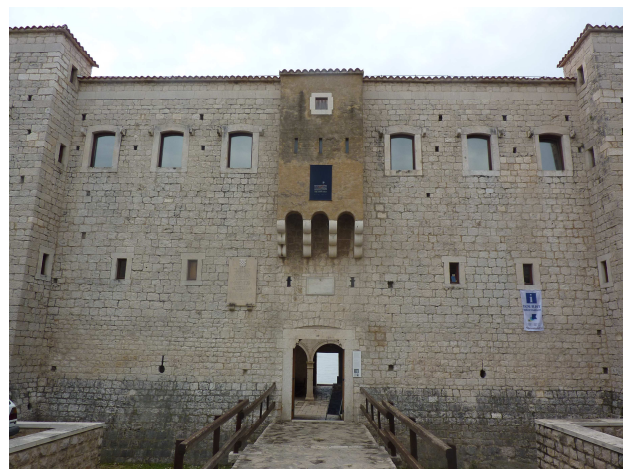

Fig. 3. Lukšić Castle (Dragos Cosmescu).

The Gomilica Castle was built in the first half of the 16th century by Benedictine monks from Split on a reef opposite the shore. The complex was only guarded by a strong gate-tower, square and very wide, with a protruding upper level which made room from all-around machicolations. The interior structure of the tower features some the old wooden elements. The perimeter has been inundated by more recent housing, which rendered its original design almost invisible.

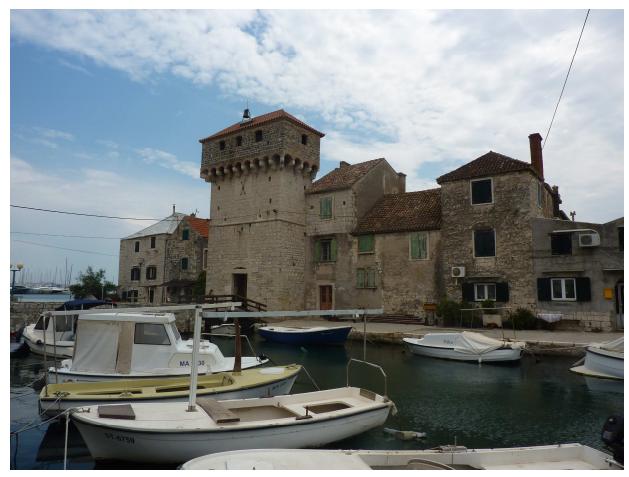

Fig. 4. Gomilica castle (Dragos Cosmescu).

The Kambelovac Castle was built by the aristocratic family Cambi from Split (1589). The most important feature is the cylindrical tower. The round tower of Cambi is a rare feature in the landscape, crowned with an upper level resting on all around machicolations.

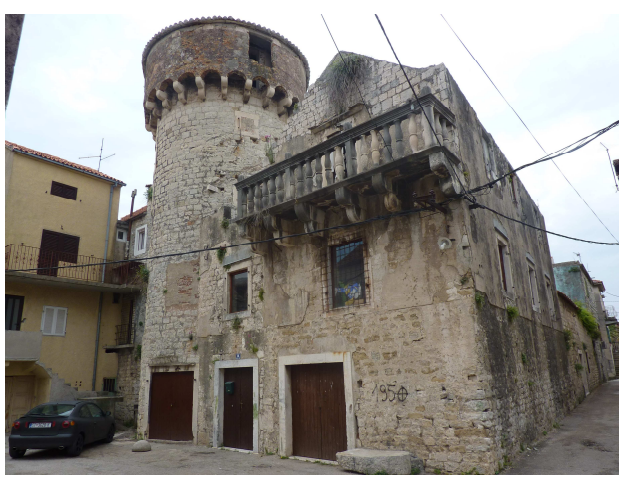

Fig. 5. Kambelovac castle (Dragos Cosmescu).

Like Kambelovac, the Castles Novi and Štafilić were also the main defense for walled settlements that have developed on the shoreline. Novi Castle was built in 1512 the Cipico family. It is the rectangular keep of the fortified village developed north of the tower, protected by a defensive $7 \mathrm{~m}$ wall on the east, north and west and towers on the northeastern and northwestern corners, with the northern gate accessed over a drawbridge.

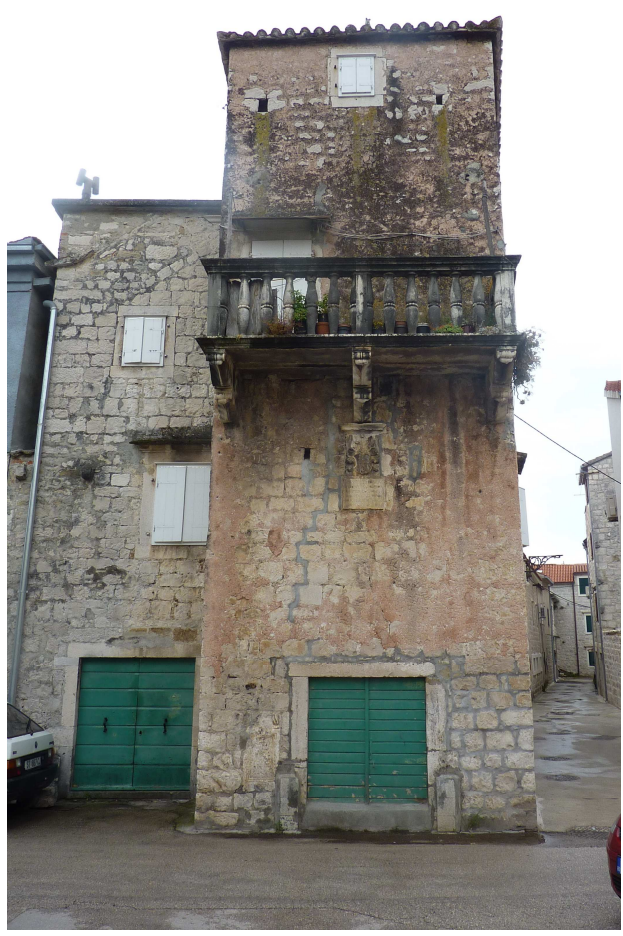

Fig. 6. Tower of Ferro (Dragos Cosmescu). 
The Štafilić castle was built in 1508 on an islet and connected with the mainland through a drawbridge. A rectangle-shaped settlement was formed around the castle, surrounded by a ditch. Ferro tower is actually part of the walled enclosure of the Štafilić village, developed north of the castle. The settlement was fortified with walls 4 to $6 \mathrm{~m}$ high, crenellated and supplanted by a wooden walkway, as well as loopholes.

The Ferro tower was originally a single-story tower with crenellations, whose traces can be still observe on its northern and western walls. It was transformed in 3-storey tower in 1603 . On the second floor on the northern façade are a Renaissance balcony and the coat of arms of the Ferro family.

North-west of this fortified village is the unfinished tower Lodi, built in 1548. The tower was built only up to the windows of the first floor and the cordon. In this case, the entrance is found ground level, and of similar design as the entrance to Voila tower (Crete). The base is very slanted and aspect is very modern for the age of artillery.

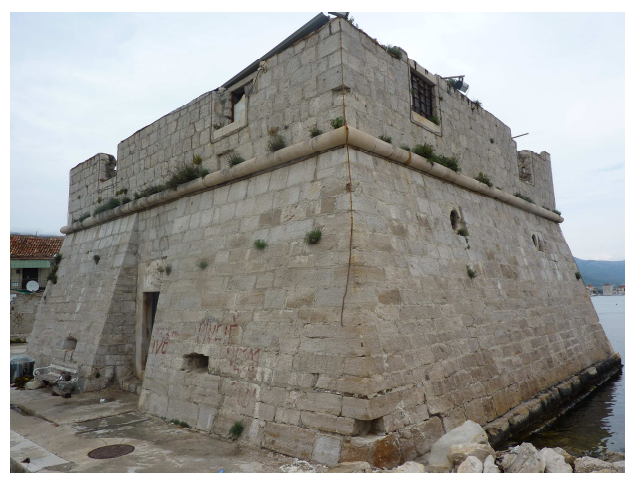

Fig. 7. Tower of Lodi (Dragos Cosmescu).

The Boglich fortified manor on the island of Hvar is one of the previously undocumented items featured in this research. It is situated in a small gulf right east of Hvar city. The complex is formed of two large houses and various dependencies, including a small loggia. Two churches are on the premises, although the older one, with medieval pediment, has lost its original purposes. One of the house is in full ruins, but the main building is still inhabited and displays exquisite features (capitals, painted ceilings, and two busts of family members from the mid-seventeenth century, one in military regalia and thus possibly associated with the long War of Candia).

From these examples, we can see that almost all were originally built on reefs and rocks by the shore, accessible by boat and with stronger landward defenses.

Besides these concentrated examples, more dispersed architectural elements can be found on the mainland (Čorić tower, Vodice), as well as the Adriatic islands, such as Kaštel Cerineo (Škrip, Brač), the keep tower at St Peter fort (Lošinj), or the tower-houses on the island of Vis: Komiza tower, Perast tower.

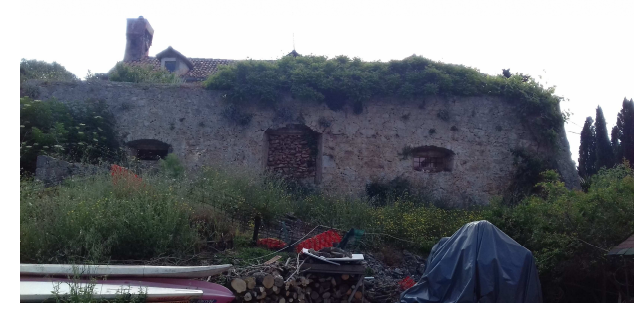

Fig. 8. Boglich manor (Dragos Cosmescu).

The defensive elements of the complex are grouped around the main house. While its walls are tall and thick, the courtyard is surrounded by slanted walls. On both side of the main entrance (now walled), are two large gun embrasures, which cover the natural road leading from the cove to the interior of the island.

\section{Corfu}

Another first-time documented item is on the island of Corfu; the tower-house situated amongst the olive plantations south and uphill of Acharavi. The structure is a tower-house, part of a fortified manor built in the center of olive harvesting and production capabilities. It is comparatively inland with the distance of heritage village of Old Perithia from the shores, and they signal a move inland characteristic of the Mediterranean under threat from Turkish pirate raids between the battles of Prevezza and Lepanto. We can thus deduce the sixteenth century as likely date of the construction of this tower house.

To the north of the enceinte is the fortified house, a three-floor tower. The walls are thicker on the ground floor and sloping, and the ground 
floor is barrel vaulted, typical of storage chambers in such country houses. A stone cordon marks the top of the first floor and another one the start of the roof. Only the vertical walls are standing, but the square tower has a separating wall going south-north. There are large windows on all sides, from the first floor up, which also indicates it suffered modification in times of peace. From the top of the keep, the coastal area around Acharavi would be visible. Access to the tower house of through a stone staircase in the shape of letter L, amongst the best preserved such element in situ.

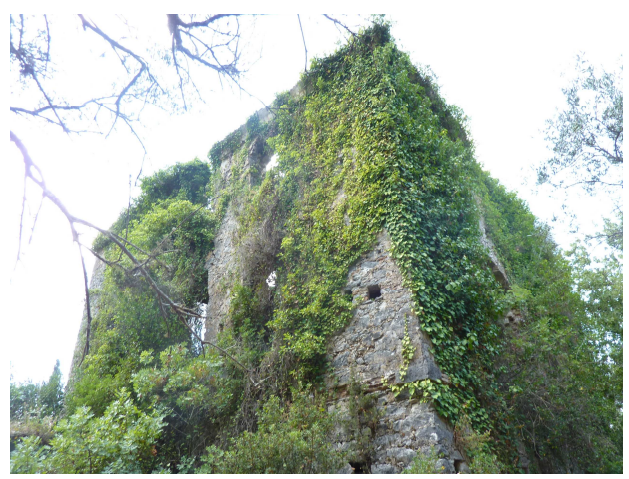

Fig. 9. Tower of Acharavi (Dragos Cosmescu).

The complex also features a small single-nave church (dedicated to St. Mary of Blachernae), with doorframes and window frames with keystones and the ruins of long storage facilities on the east side, with three halls, of which only the vertical walls remain. There is a very large courtyard, but the outer wall is however shallow, not significantly tall to be considered an active defensive feature. On three sides, the perimeter is on a small elevation, and features a small ravine action as a moat. The long wall on the west and south are preserved, but only the right half of the gate portal remains, with an oculi.

We can see here the morphology of the tower house as fortified residence in the Venetian East which includes a slanted ground level, with a decorative cordon between this and the first floor, and access over detached staircase to first floor entrance.

The Acharavi tower is actually rather similar in design to the keep of the fort of Sitia on the island of Crete. In origin a large tower house, Sitia was later expanded to include a courtyard and raised gate, and later from this perimeter de- scends walls than enclosure the small city below on both sides. The Sitia Keep has the same slanted ground level, and is smaller, but much wider. The south-west corner features a well preserved sentry box.

\section{Crete}

Further south, the island of Crete is home to a very large number of Venetian tower-houses, in various shapes and levels of preservation (e.g. Kornaros, Foscolo, Vainia, Voila, Giannoudi, Maroulas, etc.). The seventeenth century Syggelos tower, south of Rethymnon, is a good example of the Venetian rural architecture in Crete, and it consists of a rectangular 3-levels tower, next to an industrial building (olive oil press facility). Tower of the Sanguinazzo family existed in the area of Pirghos, at the seaside, and was so important it featured in most of the Venetian maps of the time.

Another a 3-storey tower from the late 16th century is in Giannoudi. This tower is a much rougher affair, but all the Veneto-Cretan features are here: entrance at the second level, cordon, slightly slanted ground floor, machicolation over doorway (here it was later modified into a long chimney for a fireplace on the top floor).

Also in this province of Rethymnon is the village of Maroulas, where we find a large towertower, a three-floor building with a height of over $14 \mathrm{~m}$. The first floor was not directly accessible from the barrel-vaulted ground floor (used as store room), but over a staircase L-shaped (like in Acharavi) and the doorway was bridged with a wooden plank 1,5 m apart.

The tower presents a solid machicolation above the entrance (which is situated at the second level and accessed over a stone stairwell). The first two levels are separated by a cordon, but this not been preserved complete. The inclination at ground level is barely acknowledgeable.

At the roof level are the main defenses, in the form of a raised parapet with loopholes and crenellations. The roof also features two sentry boxes, of which the one over the north-east corner might have evolved from an earlier machicolation. Several oculi have also been preserved, a rare presence in Cretan country houses.

Like in Acharavi, the tower in Maroulas is linked to industrial processes, having a wine 
press complex on the eastern side of the tower, and also oil-presses at its west.

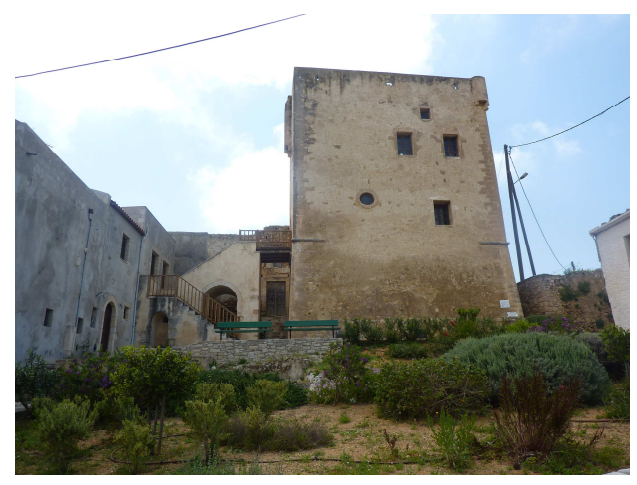

Fig. 10. Tower of Maroulas (Dragos Cosmescu).

There is also a second tower-house preserved in Maroulas it is above $10 \mathrm{~m}$ high and has three floors, also with a machicolation over the entrance. Here there is virtually no inclination at ground level. The erosion of the rougher stones forming the walls allows a superb view of the superior material forming the cordon. The entrance is also at first level, but have sediments blunt the original height of this feature. This towers also sport he remains of the supporting corner structure of the sentry box, now gone. It is also connected to an olive oil press facility, and was built in the fifteenth-sixteenth century during Venetokratia. Later, it has been included in a property with a fine Renaissance portal.

In the eastern part of Crete, the tower of Voila is also associated with industrial processes, major olive oil area, thus falling into the medieval pattern of securing production areas with suitable defenses, common in the whole Latin east.

Voila is very wide, similar in footprint with Acharavi tower. The ground floor is also barrel vaulted (like in Maroulas, Acharavi, etc.), which would indicate possible use as a storage facility. Other Venetian elements include the cordon (albeit rudimentary) and a slopped first level. While some elements (like the doorway inscription) are Turkish, they are later additions to an already existing tower house. It would be uncharacteristic to find Ottoman constructed fortified houses in Crete so early in the eighteenth century. A counter argument is the design of the doorway on the ground flood, which might very well be a Turkish change, altogether there are no identifiable signs of its potential position on the second floor, on either side of the tower. From the inside, it all too visible that the entrance was in fact larger and was only reduced in Turkish times, a practice widely spread in their alterations.

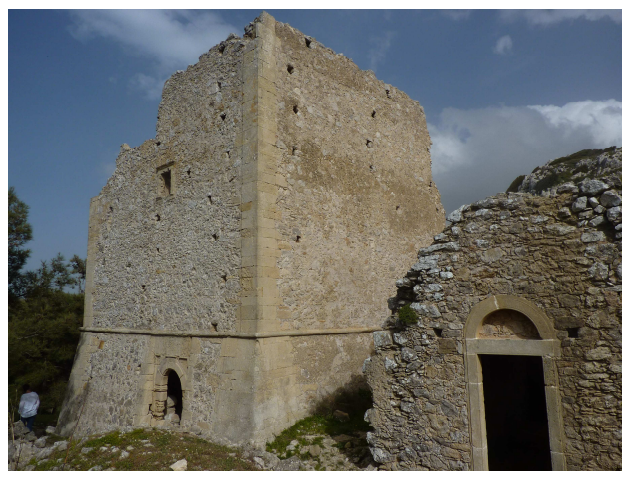

Fig. 11. Tower of Voila (Dragos Cosmescu).

\section{Conclusions}

The forms of the Venetian private rural fortifications are many and vary across space and period, not only in their design, structure and construction techniques, but also role, form, and relationship with the environment.

We underlined the architype of a tower-house vinculated to agricultural industrial facilities. The main structural common features of this are the entrance on the second level, scarped ground level, external stone staircase with wooden bridge to the doorway, use of the ground level as storage facility, presence of the cordon between the first and second levels, machicolations over the entrance.

In the Adriatic, settlements developed around such forts, and efforts were made to turn these Venetian feudal mansion-towers into more suitable accommodations, with embellishments and decorations, that dissipate their initial purpose.

While in the East we find stern, austere towers defenses associated with the industrial production- in the Adriatic we can find more palatial estates.

We also presented two new items, whose further exploration is the object of the subsequent research (which should also explore the widening the variety of the comparation by approaching the location maps and planimetries of the structures). 


\section{Bibliography}

Avcioglu, N.; Jones, E. (2013). Architecture, Art and Identity in Venice and Its Territories, 1450-1750, Ashgate, London.

Boas, A. (1999). Crusader Archaeology. The Material Culture of the Latin East, Routledge, London.

Brown, H. (1925). Dalmatia, R. \& R. Clark, Edinburgh.

Buonsanti, M.; Galla, A. (2004). Candia Veneziana: Venetian Itineraries Through Crete, Mystis, Heraklion.

Cosmescu, D. (2016). Venetian Renaissance Fortifications in the Mediterranean, McFarland \& Company, Jefferson, USA.

Curuni, A.S.; Donati, L. (1988). Creta veneziana. L'Istituto Veneto e la Missione Cretese di Giuseppe Gerola. Collezione fotografica 1900-1902, Istituto Veneto di Scienze, Lettere ed Arti, Venice.

Davies, S.; Davis, J., coord. (2007). Between Venice and Istanbul: Colonial Landscapes in Early Modern Greece, Hesperia Supplements, vol. 40, The American School of Classical Studies at Athens, Athens.

Drago, M. (1938). Nas Jadran, Izdao Arhiv za Propagandu Jadrana, Split.

Foscan, L. (2008). Guida ai castelli e ai luoghi fortificati dell'Istria, Centro per le architetture militari dell'Alto Adriatico, Trieste.

Georgopoulou, M. (2003). Venice's Mediterranean Colonies, Cambridge University Press, Cambridge.

Gerola, G. (1905-1931). Monumenti veneti nell'isola di Creta, Real Istituto Veneto di Scienze, Lettere ed Arti, Venice.

Glavaš, I. (2016). "Čorićev toranj u Vodicama - šibenska komunalna utvrda", Godišnjak zaštite spomenika kulture Hrvatske, 40, pp. 81-90.

Ivasovic, D.F. (1940). Kastel-stari. Crtice iz njegove povijesti i zivota, Leonora Tiskara Ed., Split.

Langdon, M.K. (1995). "The Mortared Towers of Central Greece", An Attic Supplement, The Annual of the British School at Athens, 90.

Lock, P. (1999). "The Medieval Towers of Greece. A problem of chronology and function", in Mediterranean Historical Review 4/1, Routledge, London, pp. 129-145.

Maglio, E. (2016). "Tower mansions in Crete. A Multidisciplinary approach to learn built heritage", in FORTMED 2016. Defensive architecture of the Mediterranean XV to XVIII Centuries, Dipartimento di Architectura (DIDA), Florence, pp. 487-494.

Scroccaro, M. (2014). Dalle torri ai forti: itinerari tra le strutture difensive dell'Alto Adriatico, Regione del Veneto, Venice.

Virgilio, G., coord. (2017). Un viaggio tra le opere fortificate di Carinzia, Canal del Ferro-Valcanale e Penisola d'Istria, Andrea Moro Ed., Trieste. 
